\title{
Features of Zoobenthos Long-Term Dynamics in Regulated Area of Ob River
}

\author{
Liubov V. Yanygina* \\ Institute for Water and Environmental Problems of SB RAS \\ 1 Molodezhnaya Str., Barnaul, 656038, Russia \\ Altai State University \\ 66 Dimitrov Str., Barnaul, 656099, Russia
}

Received 11.05.2016, received in revised form 17.07.2016, accepted 19.11.2016

The abundance, biomass and taxonomic structure of dominant zoobenthos species in Novosibirsk reservoir have been analyzed for the entire period of the reservoir existence. The formation of the bottom zoocenoses has been divided into four major stages. Despite significant differences in the dominant species composition and total biomass between the stages, the biomass of zoobenthos without shellfish had similar values (about $2,5 \mathrm{~g} / \mathrm{m}^{2}$ ) over the last 50 years. In the last two decades, the dynamics of the total benthos biomass was determined by invasive gastropods Viviparus viviparus (Gastropoda, Viviparidae).

Keywords: zoobenthos, stages of formation, the Novosibirsk reservoir, invasion.

DOI: $10.17516 / 1997-1389-2016-9-4-427-440$.

(C) Siberian Federal University. All rights reserved

* Corresponding author E-mail address: zoo@iwep.ru 


\title{
Особенности многолетней динамики зообентоса на зарегулированном участке реки Оби
}

\author{
Л.В. Яныгина \\ Институт водных и экологических проблем СО РАН \\ Россия, 656038, Барнаул, ул. Молодежная, 1 \\ Алтайский государственный университет \\ Россия, 656099, Барнаул, ул. Димитрова, 66
}

Проанализированы тенденции изменения численности, биомассы и таксономической структуры комплекса доминирующих видов зообентоса за весь период существования Новосибирского водохранилища. Выделены четыре основных этапа формирования донных зооченозов водохранилища. Несмотря на существенные различия состава доминирующих видов и значений общей биомассы зообентоса на различных этапах формирования экосистемы Новосибирского водохранилища, биомасса зообентоса без моллюсков на протяжении более чем 50-летнего периода существования водохранилища имела сходные значения и составляла около $2,5 \mathrm{c}_{\mathrm{M}^{2}}$. В последние два десятилетия динамику общей биомассы зообентоса Новосибирского водохранилища определяют брюхоногие моллюски инвазивного комплекса Viviparus viviparus (Gastropoda, Viviparidae).

Ключевые слова: зообентос, этапы формирования, Новосибирское водохранилище, инвазии.

\section{Введение}

Регулирование речного стока является одним из необходимых условий рационального использования речных ресурсов. Это определяет расположение крупных водохранилищ в зонах интенсивного экономического развития, обладающих большей потребностью в водных ресурсах для энергетических, коммунально-бытовых, рекреационных и технических целей. Эти же факторы определяют и высокую антропогенную нагрузку на экосистемы водохранилищ, приводящие в том числе к структурным перестройкам водных биоценозов, ухудшению качества воды.

Несмотря на регулирование стока, водохранилища, как и реки, относятся к числу высокодинамичных систем, что обусловлено как неравномерностью гидрометеорологических процессов, определяющих гидрологический режим водоема, так и изменениями водоема в результате его хозяйственного использования, а также целенаправленными перестройками режима эксплуатации водохранилищ при изменениях потребностей водопользователей. Эти факторы, а также особенности внутриводоемных процессов определяют специфичность развития экосистем отдельных водохранилищ и их динамики. Вместе с тем общность происхождения и элементов управления обусловливают наличие и общих черт в развитии водохранилищ различных природных зон.

На территории России наиболее зарегулирован крупными водохранилищами сток Волги и Енисея. В бассейне Оби расположено три крупных водохранилища, два из которых регулируют сток Иртыша и один - Оби 
(у г. Новосибирска). Новосибирское - единственное крупное равнинное водохранилище Сибири, что определяет особый интерес к изучению процессов формирования и динамики его экосистем. Целью данной работы стало изучение структурных характеристик донных сообществ Новосибирского водохранилища на различных этапах его формирования для выявления тенденций их многолетних изменений. Были поставлены задачи анализа численности, биомассы и таксономической структуры доминирующего комплекса видов зообентоса на различных этапах формирования водохранилища; установления факторов, определяющих динамику донных сообществ; оценки влияния сезонного изменения уровня воды на зообентос.

\section{Материалы и методы}

\section{Характеристика водоема}

Новосибирское водохранилище создано на р. Оби в 1957 г. Это водохранилище сезонного регулирования имеет протяженность около 200 км; площадь зеркала при нормальном подпорном уровне (НПУ) 1070 км², максимальная ширина 22 км, максимальная глубина 25 м, средняя глубина 9 м, средний коэффициент внешнего водообмена 6,55 (Многолетняя динамика..., 2014). Это водохранилище относится к крупным по полному объему, очень крупным по площади зеркала, средним по глубине и используется для нужд энергетики, водного транспорта, ирригации, водоснабжения, рыбного хозяйства и рекреации. Амплитуда колебаний уровня водохранилища составляет в среднем 5 м, при этом при сработке уровня осушается около 30 \% площади (Савкин, 2000). По морфометрическим показателям водохранилище можно разделить на четыре зоны: верхнюю, среднюю, нижнюю и приплотинную.

\section{Методы сбора материала}

Пробы донных отложений в зарослях макрофитов отбирали преимущественно дночерпателем Гр-91 с площадью захвата

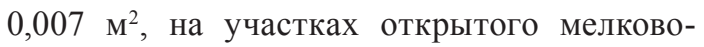
дья и в глубоководных зонах - коробчатым дночерпателем с площадью захвата $0,025 \mathrm{~m}^{2}$. В каждой точке отбирали по два дночерпателя. Донные отложения промывали через капроновый газ с размером ячеи $350 \times 350$ мкм, выбирали животных и фиксировали их 70\%ным этиловым спиртом. После установления постоянного веса определяли таксономическую принадлежность животных, считали их и взвешивали на торсионных весах ВТ-500. В работе приведены значения сырой массы организмов, измеренной после удаления поверхностной влаги фильтровальной бумагой (Руководство..., 1992).

Характеристика участков отбора проб и объем материала

Русловые участки Новосибирского водохранилища были обследованы 25-29 июля 2007 г., 22-26 июля 2008 г., а также 2326 июня, 30 июля-6 августа и 2-3 октября 2009 г. Исследования зообентоса проводили на шести створах, относящихся к четырем основным участкам: верхнему (в районе г. Камень-на-Оби), среднему (створы напротив сёл Спирино-Чингисы и Н. КаменкаОрдынское), нижнему (створы напротив сёл Боровое-Быстровка и Ленинское-Сосновка) и приплотинному (глубоководная часть перед плотиной и устье Бердского залива). На всех створах, кроме приплотинного, было выбрано по три точки отбора проб - у противоположных берегов и в центре водохранилища. Для анализа особенностей пространственного распределения Viviparus viviparus (Linnaeus, 1758) в Новосибирском водохранилище были дополнительно обработаны 34 пробы моллю- 
сков, отобранные коробчатым дночерпателем с площадью захвата 0,025 м $^{2}$ в июне, августе и сентябре 2010 г., августе 2012 г., июне, августе и октябре 2013 г., июне и августе 2014 г.

Литоральные участки обследовали 4-7 июня, 9-18 августа и 7-9 октября 2013 г., а также 12-17 июня и 9-18 августа 2014 г. Пробы зообентоса отбирали вдоль трансекты от прибрежных заросших участков к более глубоководным открытым участкам. Вдоль трансекты, как правило, выбирали четыре участка: в зарослях рогоза, зарослях болотноцветника, открытая литораль у края зарослей и удаленный участок открытой литорали. Всего было заложено три трансекты: на Крутихинском и Ирменском мелководьях и в Бердском заливе. Всего за период исследований было отобрано и проанализировано 210 проб зообентоса и 34 пробы моллюсков Viviparus viviparus.

\section{Статистический анализ}

Статистический анализ данных проводили с использованием программы «Statistica 6.0». В связи с отклонением данных от нормального распределения во всех анализируемых выборках применены непараметрические методы статистики. При сравнении выборок (например численности, биомассы, числа видов на различных участках водохранилища) использовали непараметрический метод Краскела-Уоллиса. Нулевую гипотезу об отсутствии различий между выборками отвергали при $p<0,05$.

\section{Результаты и обсуждение}

Этапы формирования

бентосных сообществ

\section{Новосибирского водохранилища}

До создания водохранилища донные отложения данного участка р. Оби были слабо заселены беспозвоночными животными. Средняя биомасса зообентоса на преобладаю- щих песчаных грунтах составляла 0,04 г/ $\mathrm{M}^{2}$, на песках с детритом - 0,12 г/м² (Мамина, 1940; Романова, 1963); на этих участках доминировали преимущественно хирономиды. На незначительных по площади каменистогалечниковых грунтах биомасса зообентоса увеличивалась до 4,85 г/м² при доминировании видов родов Simullium, Heptagenia, Hydropsyche. После зарегулирования стока p. Оби начались существенные перестройки структуры его донных сообществ. В формировании бентосных сообществ Новосибирского водохранилища можно выделить четыре основных этапа (Yanygina, 2011).

Первый этап формирования бентоса Новосибирского водохранилища приурочен к периоду его заполнения (1957-1959 гг.). В первый же год наполнения водохранилища литореофильные биоценозы были полностью разрушены. Заиление песчаных грунтов бывшего русла реки привело к увеличению биомассы зообентоса (осенью до 2,0 г/м²) преимущественно за счет развития личинок хирономид рода Chironomus (Благовидова, 1961). Летом в период вылета хирономид, составлявших основу монодоминантного сообщества, биомасса зообентоса существенно снижалась (до $0,5-0,7 \Gamma / \mathrm{M}^{2}$ ). Во второй год наполнения водохранилища отмечено увеличение биомассы двустворчатых моллюсков семейств Sphaeriidae и Pisidiidae, расселившихся из затопленных проток на участки бывшего русла реки, что стало возможным благодаря снижению скорости течения и заилению речных песков. Это привело к существенному росту

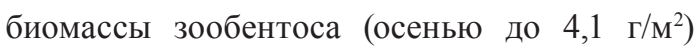
(Благовидова, 1961). Одновременно увеличение глубин на затопленной пойме вызвало отмирание высшей водной растительности, что привело к снижению биомассы фитофильных легочных моллюсков, обитавших в заросших пойменных водоемах и протоках (Благовидо- 
ва, 1969). Особенностью этого этапа для Новосибирского водохранилища является сравнительно длительный период его наполнения. Поэтому в один и тот же период на одних участках водохранилища еще шло расселение гидробионтов из поймы, а на других - уже отмечалось увеличение биомассы хирономуса и переход к следующей стадии формирования донных сообществ.

В первые годы после заполнения (19591962 гг.) в зообентосе Новосибирского водохранилища, как и других равнинных водохранилищ, отмечено массовое развитие личинок рода Chironomus - «мотылевая стадия», что обусловлено поступлением большого количества органики с затопленных территорий (Благовидова, 1976). Так, средняя биомасса зообентоса Новосибирского водохранилища в октябре 1959 г. составила 8,5 г/м², причем 85 \% биомассы приходилось на хирономид рода Chironomus. Биомасса и доля хирономид в общей биомассе зообентоса снизились уже на 3-4-м году существования Новосибирского водохранилища.

На следующем этапе формирования зообентоса, получившем название «стадия беззубки», в Новосибирском водохранилище широкое распространение и массовое развитие получили крупные двустворчатые моллюски Colletopterum piscinale (Nilsson, 1822) (Unionidae). Впервые эти моллюски были обнаружены в среднем плесе водохранилища в 1961 г., а в 1962-1964 гг. они уже составляли 63-66 \% биомассы зообентоса приплотинного участка и 62-90 \% - среднего участка (Благовидова, 1969). В 1970-1971 гг. средняя по водохранилищу численность рода Colletopterum составляла 0,6 экз $/ \mathrm{M}^{2}$, а средняя биомасса в отдельные периоды достигала

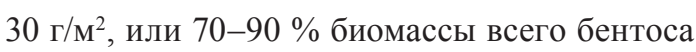
(Благовидова, 1976). Крупные двустворчатые моллюски относятся к мощным биофильтра- торам, способствующим очищению водоема. При средней скорости фильтрации воды 0,5 л/ч (Kryger, Riisgard, 1988) моллюски профильтровывали весь объем Новосибирского водохранилища за три года, что служило значимым фактором самоочищения водоема. Однако стабилизации бентосных сообществ на этом этапе не произошло. Уже в 1981-1982 гг. биомасса рода Colletopterum в Новосибирском водохранилище резко сократилась (Миронова, 1985), а в период наших исследований этот моллюск не был обнаружен. Следует отметить, что Colletopterum anatinum (Linnaeus, 1758), единично встречавшийся в 1960-е гг. в заливах водохранилища, сохранил свое значение на этих участках до сих пор. Снижение роли двустворчатых моллюсков в бентосном сообществе ведет к снижению потенциала биологического самоочищения водоема и может быть связано с органическим загрязнением водоема (Макрушин, 2002). Возможно, решающим фактором снижения численности моллюсков $C$. piscinale в Новосибирском водохранилище стал длительный маловодный период, приведший к увеличению концентрации биогенных и органических веществ в воде и снижению концентрации кислорода. Сохранение C. anatinum, очевидно, связано с его обитанием в заливах на участках впадения небольших рек, что обеспечивает проточность воды и препятствует образованию заморных зон.

На современном этапе, на «стадии живородки», существенное влияние на структуру зообентоса Новосибирского водохранилища оказывают брюхоногие моллюски Viviparus viviparus, впервые обнаруженные в водоеме в начале 1990-х гг. Уже в первое десятилетие после вселения продукция живородки $V$. viviparus превышала продукцию всего остального зообентоса водохранилища (Селезнева, 2005). Учитывая, что последние 
два десятилетия уровень продуктивности донных сообществ водохранилища определяется преимущественно живородкой, мы проанализировали особенности межгодовой динамики этого вида на различных участках водохранилища за последние 7 лет (рис. 1). В течение этого периода моллюски встречались на различных участках водохранилища очень неравномерно, при этом максимальная частота встречаемости и наибольшие значения биомассы приурочены преимущественно к средней части водохранилища (створы у сёл Спирино и Ордынское). Минимальные значения частоты встречаемости и биомассы отмечены на верхних участках водохранилища. В 2013 г. живородки были впервые встречены в Бердском заливе водохранилища, при этом на участках, где вид был обнаружен впервые, отмечены очень высокие (до 4 кг/. ${ }^{2}$ ) значения биомассы, что позволяет предположить, что моллюск продолжает активно осваивать новые участки в водохранилище (рис. 1).
Более подробный анализ особенностей динамики биомассы живородки на участках с максимальной встречаемостью (у пос. Ордынское) показал отсутствие выраженных тенденций сезонных и многолетних изменений: в отдельные годы отмечали как увеличение биомассы моллюсков к концу лета, так и отсутствие изменений в течение вегетационного сезона; в межгодовом аспекте периоды увеличения биомассы также чередовались с периодами низких значений, в одни и те же сезоны в разные годы (например, в августе) биомасса различалась на порядок (рис. 2). Вероятнее всего, такие колебания зарегистрированных значений биомассы связаны со значительной агрегированностью распределения особей. Устойчивой тенденции к снижению биомассы живородки, что характерно для чужеродных видов после стадии «взрыва численности» (Карпевич, 1975), для Новосибирского водохранилища пока не прослеживается.

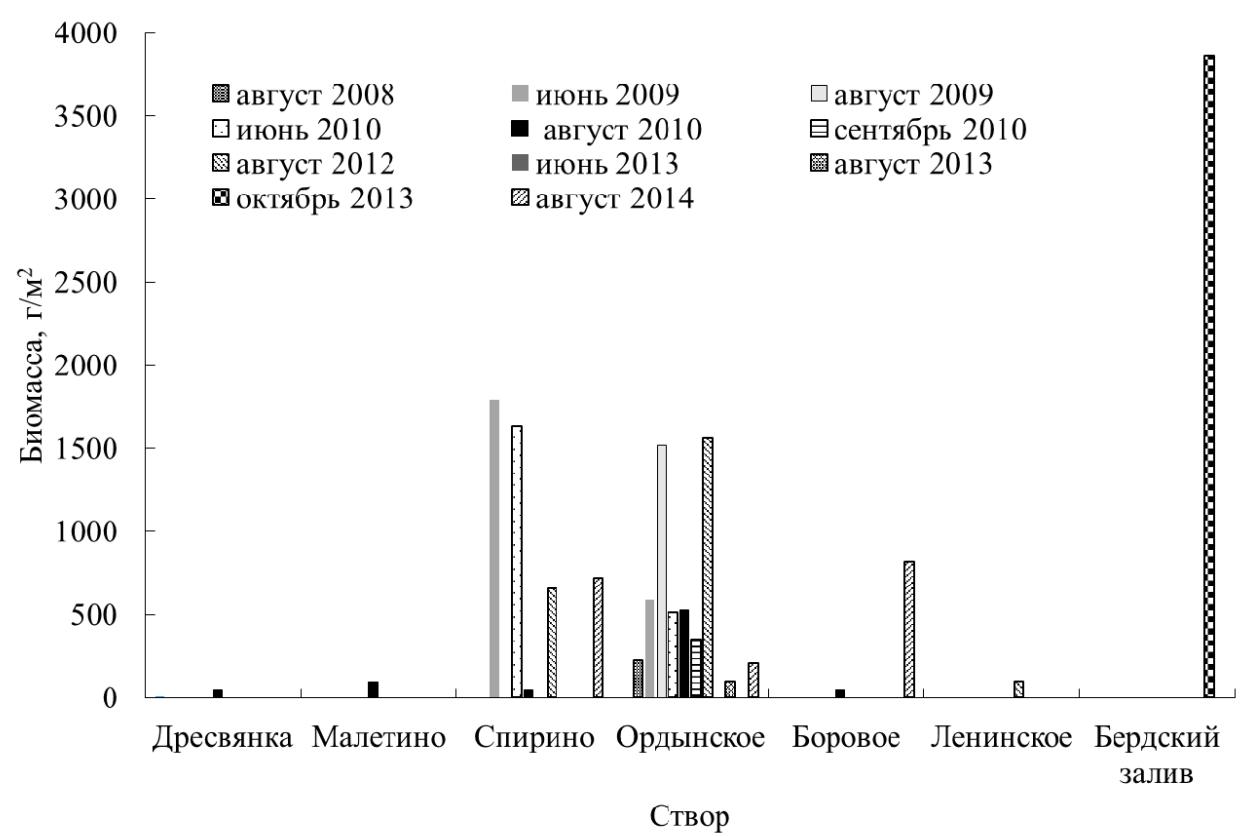

Рис. 1. Биомасса Viviparus viviparus на различных участках Новосибирского водохранилища в 20082014 гг. 


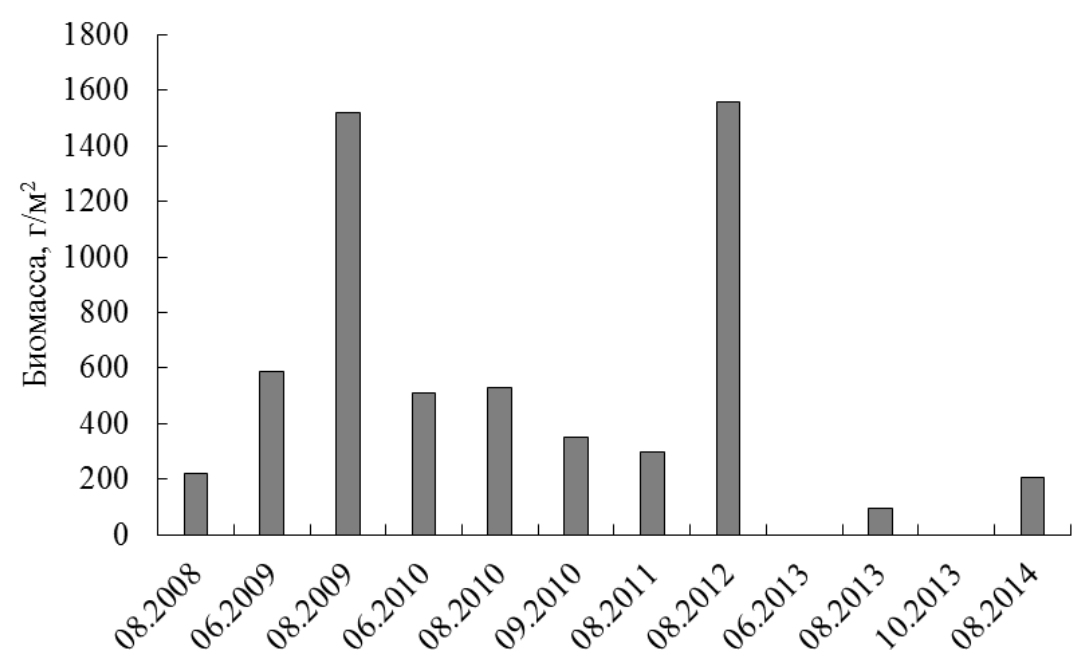

Рис. 2. Динамика биомассы Viviparus viviparus в средней части Новосибирского водохранилища (у пос. Ордынское) в 2008-2014 гг.

Сравнение таксономического состава и структуры бентосных сообществ участков с различным уровнем развития $V$. viviparus показало, что расселение моллюсков на отдельных участках средней части водохранилища привело к перестройке структуры зообентоca. На участках массового развития моллюсков отмечено незначительное снижение числа видов и видового разнообразия (по индексу Шеннона) бентосных сообществ, а также повышение численности и биомассы зообентоса по сравнению с незаселенными $V$. viviparus зонами (Yanygina, 2012).

Несмотря на случайный характер попадания этого моллюска в Новосибирское водохранилище, широкое распространение его по водоему вполне закономерно и обусловлено экологическими условиями, создающимися в русловых водохранилищах. Речная живородка $V$. viviparus предпочитает слабопроточные местообитания с невысоким содержанием ила в донных отложениях. В то же время эти моллюски требовательны к содержанию в воде кальция (Жадин, 1952; Березкина, Аракелова, 2010). Такие условия часто создаются в русловых водохранилищах, что и предопределяет успешное освоение живородками водоемов этого типа. V. viviparus является обычным компонентом малакофауны не только Новосибирского, но и многих европейских водохранилищ (Jezewski, 2004; Jakubik, 2006; Hubenov, 2007). Расселение вивипарид из пойменных водоемов и затонов на затопленные участки суши наблюдалось при формировании зообентоса ряда волжских водохранилищ (Куйбышевское, Волгоградское, Горьковское) (Мордухай-Болтовской, 1971). Этот вид имеет высокую частоту встречаемости и образует значительную часть биомассы зообентоса Камского, Воткинского, Саратовского водохранилищ (Алексевнина, Преснова, 2008; Истомина, 2008; Михайлов, 2015).

Несмотря на существенные различия состава доминирующих видов и значений общей биомассы зообентоса на различных этапах формирования экосистемы Новосибирского водохранилища, следует отметить, что биомасса зообентоса без моллюсков на протяжении более чем 50-летнего периода су- 


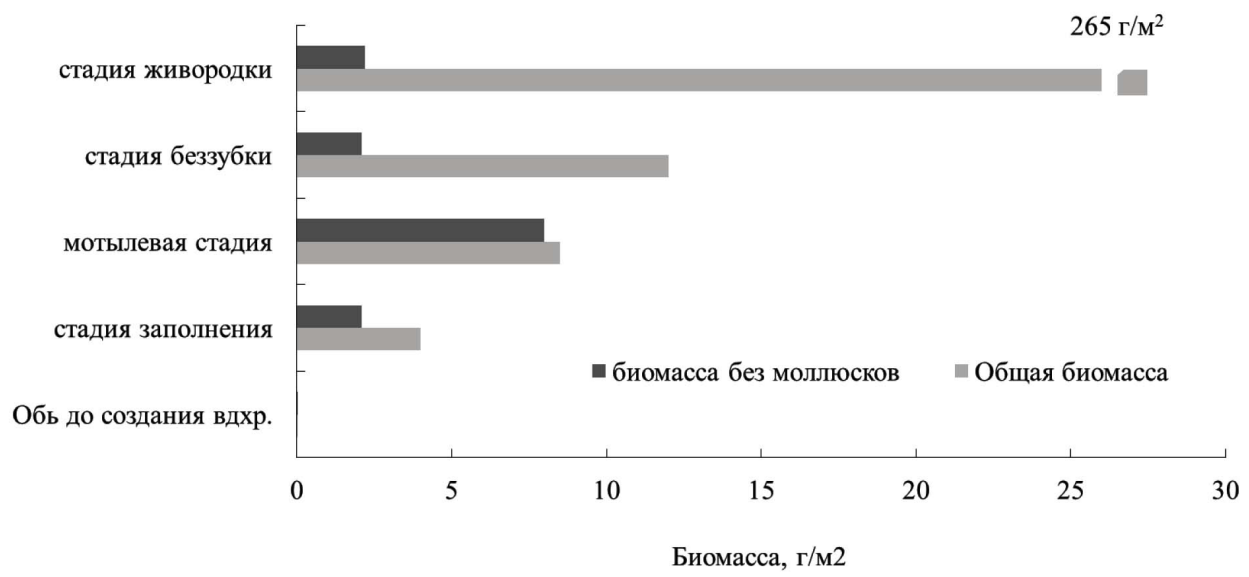

Рис. 3. Биомасса зообентоса Новосибирского водохранилища на разных этапах его формирования

ществования водохранилища имеет сходные значения и составляет около 2,5 г/M ${ }^{2}$ (рис. 3). Таким образом, в многолетнем аспекте динамику общей биомассы зообентоса Новосибирского водохранилища определяют преимущественно крупные моллюски. В межгодовом аспекте колебания биомассы зообентоса зависят от водности р. Обь и численности бентосоядных рыб (Селезнева, 2005). В многоводные годы увеличивается проточность водохранилища, что приводит к смыву илистых отложений, передислокации грунтов и является неблагоприятным фактором для развития зообентоса, особенно в осенний период (Селезнева, 2005).

\section{Современное состояние}

донных сообществ

Русловые участки водохранилища. В зообентосе русловой части Новосибирского водохранилища обнаружено 93 вида беспозвоночных. В среднем в каждой пробе отмечали $(5,9 \pm 2,1)$ вида. Видовое богатство зообентоса русла водохранилища снижалось от его верхних участков к нижним: в верхней части отмечено 47 видов донных беспозвоночных, в средней - 34, в нижней - 27, в приплотинной 10. Показатели видового разнообразия беспо- звоночных (по индексу Шеннона) статистически значимы (критерий Краскела-Уоллиса: $H=4,81 ; p=0,03)$ зависели от типа субстрата и увеличивались в ряду глина - ил - песок заиленный песок - песок с камнями.

Средние значения численности и биомассы зообентоса русловой части Новосибирского водохранилища (без V. viviparus) в разные годы исследований отличались несущественно (в 2007 г. - 1,9 $\pm 0,5$ тыс. экз $/ \mathrm{M}^{2}$ и $3,1 \pm 1,1 \Gamma / \mathrm{M}^{2} ;$ в 2008 г. - 1,2 $\pm 0,3$ тыс. экз $3 \mathrm{M}^{2}$ и $2,0 \pm 0,7$ г $/ \mathrm{M}^{2}$, в 2009 г. $-1,6 \pm 0,6$ тыс. экз $/ \mathrm{M}^{2}$ и $1,6 \pm 0,4$ г/м ${ }^{2}$ ) (критерий Краскела-Уоллиса для численности $H=1,43 ; p=0,49$; для биомассы $H=0,86 ; p=0,65)$. Средняя биомасса зообентоса в 2007-2009 гг. в целом укладывалась в интервал значений для 1993-2001 гг. $\left(1,9-8,4\right.$ г/м $\left.{ }^{2}\right)$ (Селезнева, 2005). Изменения биомассы зообентоса, как и видовое разнообразие беспозвоночных, статистически значимо зависели от типа субстрата (критерий Краскела-Уоллиса: $H=5,14 ; p=0,02)$. Максимальные значения численности и биомассы в период исследований отмечены на илах, минимальные - на глинистых грунтах (табл. 1). По обилию зообентоса водохранилище можно разделить на две зоны: с низким обилием (Крутихинское мелководье, верхний и 
Таблица 1. Численность (N, тыс. экз/ $\left.\mathrm{M}^{2}\right)$, биомасса $\left(\mathrm{B}, \Gamma / \mathrm{M}^{2}\right)$ и индекс видового разнообразия Шеннона (Н, бит/экз) зообентоса Новосибирского водохранилища на разных типах грунта в 2007-2008 гг.

\begin{tabular}{|c|c|c|c|}
\hline Тип грунта & N, тыс. экз/м² & $\mathrm{B}, \Gamma / \mathrm{M}^{2}$ & $H$, бит/экз \\
\hline Камни с песком & $1,1 \pm 0,4$ & $1,0 \pm 0,6$ & $2,5 \pm 0,5$ \\
\hline Заиленный песок & $2,2 \pm 0,6$ & $2,7 \pm 0,7$ & $2,1 \pm 0,2$ \\
\hline Песок & $1,4 \pm 0,4$ & $0,5 \pm 0,2$ & $1,9 \pm 0,2$ \\
\hline Ил & $2,9 \pm 0,7$ & $4,1 \pm 0,8$ & $1,7 \pm 0,2$ \\
\hline Глина & $0,5 \pm 0,1$ & $0,4 \pm 0,2$ & $1,4 \pm 0,2$ \\
\hline
\end{tabular}

средний участки водохранилища) и с повышенным (заливы, нижний и приплотинный участки водохранилища). Низкие значения численности и биомассы зообентоса в первой зоне, вероятно, связаны с преобладанием малопродуктивных песчаных грунтов. Значения численности (критерий КраскелаУоллиса: $H=4,60 ; p=0,03$ ) и биомассы (критерий Краскела-Уоллиса: $H=8,90 ; p=0,003$ ) макробеспозвоночных в нижней и приплотинной зонах водохранилища статистически значимо превышали аналогичные значения верхней и средней части. Отмечена тенденция к увеличению роли олигохет в структуре бентосного сообщества от верхних участков водохранилища к нижним. Проведенные исследования позволили районировать Новосибирское водохранилище по трем показателям: таксономическому разнообразию, численности и биомассе макробеспозвоночных. Верхний участок водохранилища характеризуется высоким таксономическим разнообразием бентоса при низких значениях численности и биомассы, средний участок - низким разнообразием при низких значениях численности и биомассы, нижний участок - низким разнообразием при сравнительно высоких значениях численности и биомассы, приплотинный участок - минимальным разнообразием при сравнительно высоких значениях численности и биомассы (рис. 4). Отмечены тенденции снижения так- сономического разнообразия гидробионтов и увеличения их численности и биомассы от верхних участков водохранилища к нижним.

Литораль водохранилища. В зообентосе литорали Новосибирского водохранилища обнаружено 97 видов беспозвоночных, большая часть которых (60 видов, из них 42 - хирономиды) относится к насекомым. Следует отметить, что хирономиды являются доминирующей по числу видов группой беспозвоночных в течение всего периода существования водохранилища (Благовидова, 1976; Миронова, 1985; Селезнева, 2005) и составляют около 40 \% общего таксономического списка. Специфический для литорали водохранилища комплекс наиболее часто встречающихся видов образовали Glyptotendipes glaucus (Meigen, 1804) (49 \% проб) и Gmelinoides fasciatus Stebbing, 1899 (46 \%). Высокая частота встречаемости отмечена также для Limnodrilus hoffmeisteri Claparede, 1862 (52 \%), Chironomus группы plumosus (61\%), Procladius ferrugineus Kieffer, 1918 (53 \%) - видов, доминирующих по встречаемости и на других участках водохранилища. Значения численности и биомассы зообентоса в отдельных пробах исследованных участков литорали изменялись в широких переделах: 0 - 22,4 тыс. экз/ $\mathrm{M}^{2}$ и $0-105,8$ г/м², при этом и минимальные, и максимальные показатели были отмечены на заросших участках литорали, что, ве- 


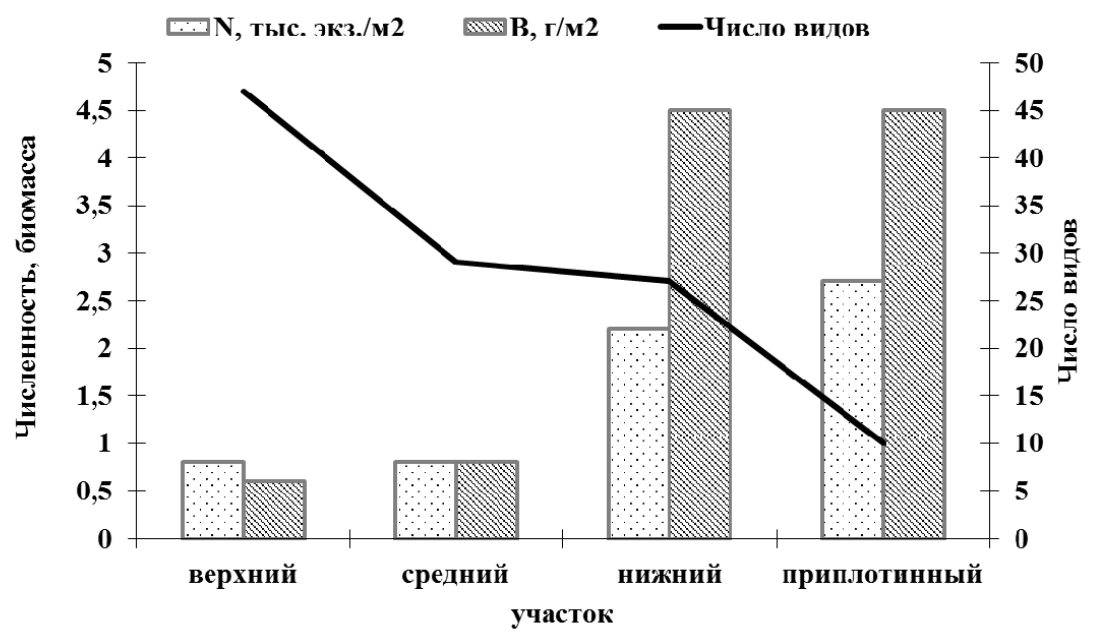

Рис. 4. Численность (N), биомасса (В) (без V. viviparus) и число видов зообентоса разных участков Новосибирского водохранилища

роятно, связано с высокой неоднородностью условий обитания зообентоса в прибрежных заросших участках водохранилища.

Важный фактор формирования литоральных донных сообществ в водохранилищах - колебания уровня воды. Обсыхание и промерзание донных отложений в период сработки уровня вызывает гибель донных организмов и снижает запасы биомассы зообентоса на прибрежных участках. Глубина сработки уровня Новосибирского водохранилища составляет в среднем 5 м, при этом осушается около 30 \% площади водоема (Савкин, 2000). В первые годы существования водохранилища сработка уровня в летний и раннеосенний безледный периоды приводила к полной гибели донной фауны на осушаемых участках и длительному ее восстановлению (до середины лета) после наполнения водохранилища (Благовидова, 1972). В последующие годы сработка уровня Новосибирского водохранилища происходила преимущественно в зимний период после установления ледостава, при этом донные отложения оставались влажными подо льдом до наполнения водо- хранилища. Исследования зообентоса Новосибирского водохранилища позволили установить выживание бентосных организмов в период зимней сработки водохранилища во влажных грунтах зоны временного осушения, при этом биомасса зообентоса на осушаемых биотопах была выше, чем в зоне постоянного затопления (Vizer, 2011). В период наших исследований, несмотря на различия графиков сработки водохранилища в 2013 г. (верхние участки литорали находились в зоне временного осушения около 3,5 месяцев) и в 2014 г. (верхние участки литорали находились в зоне временного осушения менее 2 месяцев), численность и биомасса зообентоса в конце периода наполнения водохранилища (июнь) в межгодовом аспекте статистически значимо не различались (критерий Краскела-Уоллиса для численности $H=1,10 ; p=0,29$; для биомассы $H=1,19 ; p=0,66$ ).

Сезонная динамика биомассы зообентоса на верхних участках литорали характеризовалась преимущественно двумя пиками: в июне и октябре. Снижение биомассы зообентоса в августе, вероятно, связано с повыше- 


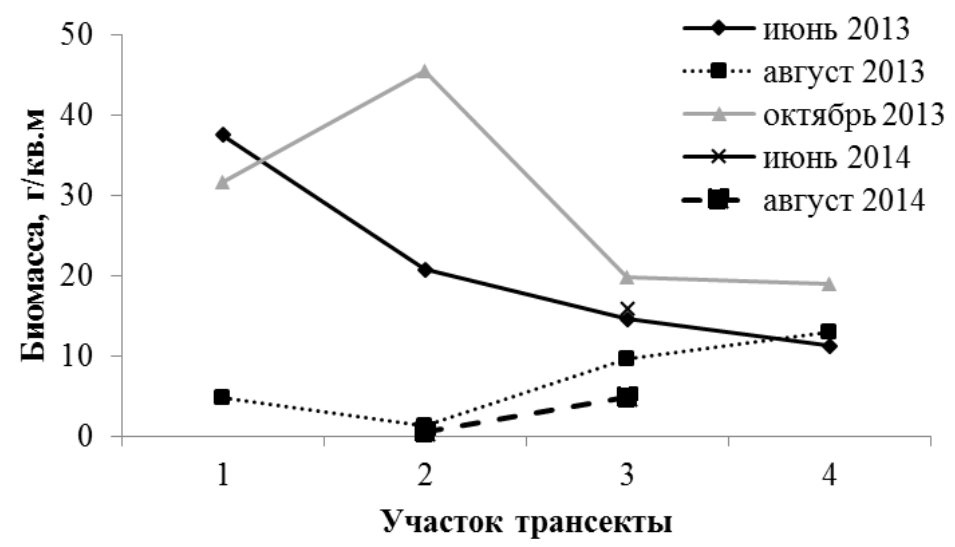

Рис. 5. Биомасса зообентоса на разных участках литорали Бердского залива вдоль трансекты: 1 - в зарослях рогоза; 2 - в зарослях болотноцветника; 3 - открытая литораль у края зарослей; 4 - удаленный от берега участок открытой литорали

нием в этот период уровня воды, которое сопровождается затоплением зоны временного осушения, увеличением площади водохранилища и, соответственно, перераспределением макробеспозвоночных на большей площади. Кроме того, в этот же период происходит активный вылет имаго амфибиотических насекомых, что также может дополнительно приводить к временному снижению значений биомассы зообентоса. В более глубоководной зоне открытой литорали сезонные изменения биомассы были менее выражены (рис. 5).

На зарастающих участках литорали доминировали по биомассе ракообразные (Gmelinoides fasciatus), моллюски (преимущественно Radix auricularia (Linnaeus, 1758), Cincinna aliena (Westerlund, 1877)) и хирономиды (преимущественно Glyptotendipes paripes (Edwards, 1929) и G. glaucus). В открытой литорали в состав комплекса доминирующих видов входили Chironomus группы plumosus, G. paripes, Cincinna aliena. Таким образом, к специфическим доминантам зарастающей литорали можно отнести G. fasciatus, открытой - Chironomus группы plumosus. В период минимального уровня воды не отмечено перестроек структуры комплекса доми- нирующих видов зообентоса по сравнению с другими периодами исследования.

\section{Заключение}

Многолетняя динамика биомассы 3ообентоса Новосибирского водохранилища характеризуется значительным развитием хирономид-детритофагов в течение 3-4 лет после заполнения водохранилища («мотылевая стадия»), преобладанием двустворчатых моллюсков-фильтраторов в последующие 20 лет («стадия беззубки») и развитием брюхоногих моллюсков-детритофагов в последние десятилетия («стадия живородки»). Несмотря на существенные различия биомассы зообентоса на разных этапах формирования, средние по водохранилищу значения биомассы без учета моллюсков за последние 50 лет различаются незначительно и составляют около 2,5 г/м². Максимальные значения биомассы зообентоса в литорали водохранилища в период исследований отмечали на периодически осушаемых зарастающих макрофитами участках верхней литорали. Характерная для Новосибирского водохранилища сработка уровня в зимний подледный период не оказывает существенного отрицательного влия- 
ния на развитие зообентоса. Для донных сообществ Новосибирского водохранилища в современный период свойственно снижение таксономического разнообразия макробеспозвоночных и увеличение их численности и биомассы от верхних участков водохранилища к нижним. Верхний участок водохранилища характеризуется высоким таксономическим разнообразием бентоса при низких значениях численности и биомассы, средний участок - низким разнообразием при низких значениях численности и биомассы, нижний участок - низким разнообразием при сравнительно высоких значениях численности и биомассы, приплотинный участок - минимальным разнообразием при сравнительно высоких значениях численности и биомассы.

\section{Благодарность}

Автор выражает благодарность М.И. Ковешникову и Е.Н. Крыловой за помощь в сборе материала.

\section{Список литературы}

Алексевнина М.С., Преснова Е.В. (2008) Изменение донных сообществ Воткинского водохранилища за время его существования (1962-2006 гг.). Современное состояние водных биоресурсов: Матер. междунар. конф. Новосибирск, с. 272-273 [Alexevnina M.S., Presnova E.V. (2008) Changes of benthic communities Votkinsk reservoir at the time of its existence (19622006). Modern condition of water biological resources: Mater. Intern. Conf. Novosibirsk, p. 272273 (in Russian)]

Березкина Г.В., Аракелова Е.С. (2010) Жизненные циклы и рост некоторых гребнежаберных моллюсков (Gastropoda: Pectinibranchia) в водоемах Европейской части России. Tpyды Зоологического института РАH, 314 (1): 80-92 [Berezkina V.G., Arakelova E.S. (2010) Life cycles and growth of some grabagailua molluscs (Gastropoda: Pectinibranchia) in the ponds of the European part of Russia. Proceedings of the Zoological Institute of the Russian Academy of Sciences [Trudy Zoologicheskogo instituta RAN], 314 (1): 80-92 (in Russian)]

Благовидова Л.А. (1969) Особенности распространения моллюсков в Новосибирском водохранилище. Вопросы малакологии Сибири. Томск, Томск. гос. ун-т., с. 113-116 [Blagovidova L.A. (1969) Peculiarities of distribution of molluscs in Novosibirsk reservoir. Issues of malacology in Siberia. Tomsk, Tomsk State University, p. 113-116 (in Russian)]

Благовидова Л.А. (1961) Формирование бентоса Новосибирского водохранилища в период его наполнения. Труды Биологического института СО АН СССР, Вып. 7, с. 91-102 [Blagovidova L.A. (1961) The formation of the benthos of the Novosibirsk reservoir during its filling. Proceedings of Biological Institute, SB AS USSR. Vol. 7, p. 91-102 (in Russian)]

Благовидова Л.А. (1972) Значение осушной зоны в формировании кормовых запасов для рыб Новосибирского водохранилища. Зоологические проблемы Сибири. Новосибирск, Наука, с. 221-222 [Blagovidova L.A. (1972) The importance of littoral zone in the formation of forage stocks for fish in Novosibirsk reservoir. Zoological problems of Siberia. Novosibirsk, Nauka, p. 221-222 (in Russian)]

Благовидова Л.А. (1976) Состояние зообентоса водохранилища на втором десятилетии его существования. Биологический режим и рыбохозяйственное использование Новосибирского водохранилища. Новосибирск, Западно-Сибирское книжное издательство, с. 83-98 [Blagovidova L.A. (1976) Status of zoobenthos reservoirs in the second decade of its existence. Biological regime 
and fishery-related use of the Novosibirsk Reservoir. Novosibirsk, Western Siberian book publishing house, p. 83-98 (in Russian)]

Жадин В.И. (1952) Моллюски пресных и солоноватых вод СССР. М.-Л., Изд-во АН СССР, 376 c. [Zhadin V.I. (1952) Mollusks of fresh and brackish waters of the USSR. Moscow-Leningrad, AS USSR, 376 p. (in Russian)]

Истомина A.M. (2008) Структура сообществ Камского водохранилища. Современное состояние водных биоресурсов: Матер. междунар. конф. Новосибирск, с. 107-110 [Istomina A.M. (2008) Community structure in the Kama reservoir. The current state of water bioresources: Mater. Intern. Conf. Novosibirsk, p. 107-110 (in Russian)]

Карпевич А.Ф. (1975) Теория и практика акклиматизации водных организмов. М., Пищевая промышленность, 427 с. [Karpevich A.F. (1975) Theory and practice of acclimatization of aquatic organisms. Moscow, Food industry, 427 p. (in Russian)]

Макрушин А.В. (2002) В промышленно развитых странах Unionidae (Bivalvia, Mollusca) вымирают. А в России? Актуальные проблемы экологии Ярославской области. Т. 2. Ярославль, Издание Верхневолжского отделения Российской экологической академии, с. 77-79 [Makrushin A.V. (2002) In industrialized countries Unionidae (Bivalvia, Mollusca) extinct. And in Russia? Contemporary problems of ecology of the Yaroslavl region. Vol. 2. Yaroslavl, Upper Volga branch of Russian ecological Academy, p. 77-79 (in Russian)]

Мамина Н.Д. (1940) Биологическая характеристика р. Оби и ее притоков в зоне г. Новосибирска. Сб. работ Новосибирского НИИ гигиены и санитарии. Вып. 8, с. 66-75 [Mamina N.D. (1940) Biological characteristics of the river Ob and its tributaries in the zone of Novosibirsk. Proc. of Novosibirsk Institute of hygiene and sanitation. Vol. 8, p. 66-75 (in Russian)]

Миронова Е.Б. (1985) Зообентос Новосибирского водохранилища. Комплексные исследования Новосибирского водохранилища. М., Гидрометеоиздат, с. 109-119 [Mironova E.B. (1985) Zoobenthos of the Novosibirsk reservoir. Complex studies of the Novosibirsk reservoir. Moscow, Gidrometeoizdat, p. 109-119 (in Russian)]

Михайлов Р.А. (2015) Эколого-фаунистический анализ пресноводных моллюсков Средней и Нижней Волги. Тольятти, Институт экологии Волжского бассейна PAH, 188 с. [Mikhailov R.A. (2015) Ecological and faunistic analysis of the freshwater molluscs of Middle and Lower Volga. Togliatti, Institute of Ecology of the Volga River Basin RAS, 188 p. (in Russian)]

Многолетняя динамика водно-экологического режима Новосибирского водохранилища (2014) Новосибирск, Изд-во СО РАН, 391 с. [Long-term dynamics of water-ecological regime of the Novosibirsk reservoir (2014) Novosibirsk, SB RAS, 391 p. (in Russian)]

Мордухай-Болтовской Ф.Д. (1971) Бентос крупных водохранилищ на Волге. Волга-1. Проблемы изучения и рационального использования биологических ресурсов водоемов: Матер. конф. Куйбышев, с. 124-131 [Mordukhai-Boltovskoy F.D. (1971) Benthos of large reservoirs on the Volga river. Volga-1. Problems of studying and rational use of biological resources of reservoirs: Proc. Conf. Kuibyshev, p. 124-131 (in Russian)]

Романова Г.П. (1963) К изучению зоопланктона и зообентоса верхнего течения реки Оби. Труды Томского гос. университета, т. 152, с. 117-125 [Romanova G.P. (1963) To the study of zooplankton and zoobenthos of the river Ob upper reaches. Proceedings of Tomsk State University, V. 152, p. 117-125 (in Russian)] 
Руководство по гидробиологическому мониторингу пресноводных экосистем (1992) СПб., Гидрометеоиздат, 320 с. [Manual on hydrobiological monitoring of freshwater ecosystems (1992) St. Petersburg, Gidrometeoizdat, 320 p. (in Russian)]

Савкин В.М. (2000) Водохранилища Сибири, водно-экологические и водно-хозяйственные последствия их создания. Сибирский экологический журнал, 2: 109-121 [Savkin V.M. (2000) Siberian reservoirs, aquatic-ecological and water-economic consequences of their creation. Siberian Ecological Journal [Sibirskij ehkologicheskij zhurnal], 2: 109-121 (in Russian)]

Селезнева М.В. (2005) Оченка современного экологического состояния Новосибирского водохранилища по структурно-функииональным показателям сообществ макрозообентоса. Автореф дис... канд. биол. наук. Новосибирск, 21 с. [Selezneva M.V. (2005) Assessment of the current ecological status of the Novosibirsk reservoir on the structural and functional parameters of macrozoobenthos communities. Abstract of Diss... candidate. Biol. Sciences. Novosibirsk, 21 p. (in Russian)]

Jakubik B. (2006) Reproductive pattern of Viviparus viviparus (Linneus) (Gastropoda, Viviparidae) from littoral aggregations in a through flow reservoir (Central Poland). Polish Journal of Ecology, 54 (1): 39-55

Jezewski W. (2004) Occurrence of Digenea (Trematoda) in two Viviparus species from lakes, rivers and a dam reservoir. Helminthologia, 41 (3): 147-150

Hubenov Z. (2007) Fauna and zoogeography of marine, freshwater and marine mollusks (Molluska) in Bulgaria. Biogeography and ecology of Bulgaria. Fet V., Popov A. (Eds.) Dordrecht, Springer, p. 141-198

Kryger J., Riisgard H.U. (1988) Filtration rate capacities in 6 species of European freshwater bivalves. Oecologia, 77: 34-38

Vizer A.M. (2011) Zoobenthos of the drainage zone of Novosibirsk Reservoir. Contemporary Problems of Ecology, 4 (1): 50-55

Yanygina L.V. (2011) The current state and long-term changes of zoobenthos in the Novosibirsk Reservoir. Inland Water Biology, 4 (2): 218-222

Yanygina L.V. (2012) The role of Viviparus viviparus (L.) (Gastropoda, Viviparidae) in formation of macrozoobenthos communities in the Novosibirsk Reservoir. Russian Journal of Biological Invasions, 3 (1): 64-70 